\title{
Leadership Styles and Customer Loyalty: A Lesson from Emerging Southeast Asia's Airlines Industry*
}

\author{
Mohamad RIZAN ${ }^{1}$, Ari WAROKKA ${ }^{2}$, Agus WIBOWO ${ }^{3}$, Ika FEBRILIA ${ }^{4}$ \\ Received: June 02, 2020 Revised: July 28, 2020 Accepted: August 10, 2020
}

\begin{abstract}
This study provides the empirical testing to test the influences of contemporary leadership styles (i.e., transactional and transformational) on job satisfaction and customer satisfaction as the mediating variable between job satisfaction and customer loyalty. The approach utilized in this study was a quantitative research design using a survey model. The participants of this study were recruited from 160 front-liners in the airline's industry in Indonesia. This study employed 160 front liners (flight attendants, reservation/ticketing, and check-in-counter officers) who worked in Branch Office/General Sales Agent of Indonesian commercial airlines. The studied airlines serve domestic routes based at Soekarno-Hatta International Airport. Furthermore, the data were examined the four developed hypotheses by using Structural Equation Modeling (SEM). The primary results are: First, in the context of job satisfaction, both leadership styles (i.e., transactional and transformational) have similar influences; Second, job satisfaction affects customer satisfaction positively and significant, Third, customer loyalty is driven by passengers' satisfaction when they are utilizing the airline services. The findings imply that the working-role encouragement is essential to maximize the productivity of front-liners to serve their customer well. This research supports on developing the general knowledge based on leadership styles in the context of the airline's industry in managing the human resources strategically.
\end{abstract}

Keywords: Transactional Leadership, Transformational Leadership, Job Satisfaction, Customer Satisfaction, Customer Loyalty, Airlines Industry

JEL Classification Code: D91, M12, M21, M52

\section{Introduction}

The implementation of AEC (ASEAN Economic Community), was in force on 1st of January 2016, has

\footnotetext{
*Acknowledgements:

We are grateful to anonymous reviewers and editor of the journal for their valuable comments and suggestions an effort to improve the quality of article.

${ }^{1}$ First Author and Corresponding Author. Faculty of Economics, Universitas Negeri Jakarta, Indonesia [Postal Address: Jl.

Rawamangun Muka Jakarta Timur, DKI Jakarta, 13220, Indonesia] Email: mohamadrizan72@unj.ac.id

${ }^{2}$ Centro Internacional "Carlos V"- Universidad Autonoma de Madrid, Spain. Email: ari.warokka@gmail.com

${ }^{3}$ Faculty of Economics, Universitas Negeri Jakarta, Indonesia.

Email: agus-wibowo@unj.ac.id

${ }^{4}$ Faculty of Economics, Universitas Negeri Jakarta, Indonesia.

Email: ikafebrilia@unj.ac.id

(c) Copyright: The Author(s)

This is an Open Access article distributed under the terms of the Creative Commons Attribution Non-Commercial License (https://creativecommons.org/licenses/by-nc/4.0/) which permits unrestricted non-commercial use, distribution, and reproduction in any medium, provided the original work is properly cited.
}

brought a dramatic impact on many aspects for all ASEAN member countries. According to ASEAN Economic Community Blueprint (2008), the AEC is the realization of the big idea to integrate all economic facets as promoted in the Vision 2020 in which all ASEAN member countries have agreed and committed to deepen and broaden its business and financial collaboration through prevailing and new strategies with clear timeframes." Related to ASEAN Vision 2020, the ASEAN leaders at their Summit in Kuala Lumpur in December 1997, has determined to develop ASEAN into a sound, well-off, and highly competitive region with impartial economic advancement, and lessened poverty and socioeconomic inequalities (ASEAN Economic Community Blueprint, 2008).

Subsequently, there are five core elements (i.e., goods, services, investment, capital, and professional labors) are freely traded and streamed to support the goal of AEC. Focusing on the free flow of trained workers, this category of effort is applied for: (1) managing flexibility or facilitating access for the unrestricted flow of people engaged in business and financial trading, based on the existing 
and established regulations for the host country, and (2) developing harmonization and standardization to facilitate the movement within the region. The unimpeded course of the qualified labor primarily enables professional and skilled ones in ASEAN to participate in the mobility of transnational business and related economic activities.

The application of ASEAN Economic Community (AEC) that skilled and productive labor is one of the crucial factors that determine any organizations sustainability. It is in line with the Emsina (2014) and Tran (2020) statement, which argues that the employed-people productivity and economic growth are crucial elements in any economy, so if a business and financial crisis happened; actually, it reflects the plight of humanity in general.

Since the role of labors or employees become significant in developing and maintaining an industry, many organizations are now attempting to retain its skilled employees, such as by giving them rewards or motivating with proper leadership style. There are two-leadership styles (i.e., transactional and transformational) which have opposite ways to motivate their employees/subordinates. Transactional leaders usually stimulate their subordinate by contingent reward while transformational ones provide more opportunities to share the vision and be more creative with its implemented strategies.

Even though many studies have explored and discussed leadership styles, there is still a gap to be empirically tested. It is related to the contradiction regarding transactional leadership in the organizational context. Since their focus on contractual agreement and also extrinsic rewards to enhance the subordinate's motivation (Bass, 1985), managerial (transactional) leaders usually impede the employee's innovative efforts, and their leadership practices negatively influence their employees' job satisfaction (Bono \& Judge, 2004). Thus, this study offers an opportunity to bridge the gap in different industry context and find out the effects of contemporary leadership styles on determinants that related to satisfaction and loyalty.

\section{Literature Review}

\subsection{Transactional and Transformational Leadership}

Sarros and Santora (2001) argue that in the managerial (transactional) leadership, employees are dealing with cost-benefit economic challenges offered by the leader or manager. This executive person would meet the employee's or follower's material and psychic needs in return for expected work performance. Transformational leaders raise the consciousness of followers by appealing to higher ideals and values such as liberty, justice, peace, and equality. Burns
(1978) distinguished those two forms of leadership, as follows: transactional leader usually provides compensations to their follower in exchange for desired behaviors and practices, while transformational leadership occurs when there is an interaction between leader and follower to enhance the levels of innovation and motivation (Menon, 2014). The relationship between leader and follower in managerial (transactional) leadership style is rooted on the reciprocal and deterministic ways; leaders use a bargaining process to motivate the subordinate's behavior. In another hand, emotion is a basis for transformational leadership whereas trust and confidence are utilized for stimulating their subordinate.

There are several characteristics of transactional leadership (Vito et al., 2014: Doan et al., 2020). First, this type of leadership applies contingent reward as a stimulation method for their subordinate when they fulfill and complete their job responsibility, and also produce the excellent performance. Second, the managerial (transactional) leader usually implements an active management-by-exception (MBE) as a monitoring program to control the work of their subordinate and predict or prevent them from deviating goals of objectives (Bass, 1985). Third, transactional leaders are non-participating in which they take action only when a problem arises, as referred as passive MBE (Judge \& Piccolo, 2004).

Similarly, there are four characteristics to describe transformational leadership (Vito et al., 2014). First, the charisma becomes a powerful tool for the transforming leaders to produce a sense of referent power. Second, this type of leaders usually can inspire their subordinate by giving an opportunity to share their vision and emotionally connected with them. Third, the connection, which is already built by leader-subordinate, is used as a mentor or advisor to develop a focus for the subordinate (i.e., individual consideration). Fourth, the transformational leader stimulates the intellectual of their subordinate by assisting them in challenging the status quo, or discussing and analyzing the classic issues in new effective ways (Bass, 1985).

\subsection{Job Satisfaction}

According to Locke (1969), the employee's job satisfaction is the pleasant mental state as a result of one's achievement appraisal or recognition on the attainment of one's job values. Meanwhile, Spector (1997) describes it as an employee's attitude, whether he or she will regard or disregard to their job responsibility, will be satisfied or dissatisfied with their job performance. Happy feelings and specific personal values resulting from employee's job could also be referred to job satisfaction (Wagner \& Hollenbeck, 2010). Moreover, job satisfaction is not only 
Mohamad RIZAN, Ari WAROKKA, Agus WIBOWO, Ika FEBRILIA /

Journal of Asian Finance, Economics and Business Vol 7 No 9 (2020) 477-488

about employee's contribution but also organization's feedback to what their employees have done (Ivancevich et al., 1997). Currently, satisfied employees are likely to be more productive; they will be more enthusiasts to provide the highest service quality to their customer, and hence significantly increased the profitability of one business (Pantouvakis \& Bouranta, 2013). Furthermore, in this study, job satisfaction is conceptualized as the emotional feelings of the airline's front-liners describing their happiness and gratification because of their ability to finish the job responsibility, serve their customer well, and get high recognition and proper compensation from their employer.

\subsection{Customer Satisfaction}

Kotler (2001) explains satisfaction as customer's feeling description, whether he or she is happy or disappointed, related to the offered product/service. It means that customers will compare their perception of the expected and received product/service's performance. Dissatisfaction happens when the performance of product/service is below the customer's expectation level, and on the other hand, if the performance is above their expectation, then, the customer will be satisfied. Zeithaml et al. (2006) argued satisfaction as the customer's cognitive and affective evaluation on the purchased product or service. Moreover, it is in line with the research of Ha et al. (2011) and Suparno et al. (2019), which states that satisfaction is conceptually revealed as an overall product or service's evaluation by the customer whom they will consider whether all the benefits of product/service met their needs or not. Therefore, customer satisfaction in this present study refers to the subjective and positive evaluations of the customer, especially passenger, toward the excellence of airline front-liners' services.

\subsection{Customer Loyalty}

Oliver (1999) proposed loyalty as a firm adherence to repurchase or redeal with a favored item or service persistently onward, in this manner bringing repetitive same-trademark or same brand-set buying, despite incidental impacts and marketing endeavors having the ability to bring about diverting demeanor. Many researchers have mostly discussed two perspectives of customer loyalty. Attitudinal (cause) is the first perspective describing loyalty as customer's desire to repurchase and maintain their relationship with the particular service providers, while behavioral (effect) is the perspective viewing customer loyalty as a repeat patronage, the percentage of real action when customers decide to purchase in a particular category. The latter is compared to the total amount of purchasing activity that has been decided by a customer in those specific categories (Yang \& Peterson, 2004).

Furthermore, customer loyalty also related to the possibility of customer to suggest good things about the service provider based on their experience; to promote positive payroll to the others and encourage them to purchase; and the conviction of the customer to select and/or decide the provider as the first choice when they need product/service in the future.

Oliver (1999) also subdivides customer loyalty into four stages (cognitive loyalty, affective loyalty, conative loyalty, and action loyalty). In subjective dependability (cognitive loyalty), commitment to rebuy product or service consistently based on product information from attribute performance levels, such as costs, benefits, and quality or value during customers' consuming process. In the second phase of loyalty (affective loyalty), the customer usually decides to buy the same brand based on their feelings or liking due to they perceive satisfied when they have consumed the product or service before. In conative loyalty, the customer desires to own the specific brand more than cognition. They did not only have a commitment but also feel trust in the brand. The last phase (action loyalty) is the action that the customer does as a result of commitment and motivated intention to rebuy the product or service.

This study is to examine the effects of transactional and visionary (transformational) leadership on job satisfaction and the intervening role of customer satisfaction within the relationship between job satisfaction and client loyalty, by proposing four hypotheses. It synthesized prior empirical findings and relevant theories to develop a logical relationship between the variables.

Prior studies (e.g., Yammarino et al., 1998; Walumbwa et al., 2008; Pihie et al., 2011; Ewen et al., 2013) revealed the essential relationship between transactional leadership and job satisfaction. In the context of the service industry, the research of Pihie et al. (2011) concludes that managerial (transactional) leadership is affirmatively correlated with the lecturers' job satisfaction. Also, they reveal that lecturers who are motivated by their transactional leader become more productive when compared to the other academic staff or employee. They will work harder to enhance and encourage the progressive development of their higher education institutions, achieve the high-quality performance and meet the students' expectation, which those efforts will trigger the high level of lecturers' job satisfaction. Similar with the previous study, Ewen et al. (2013) also clarify that contingent reward (transactional leader behavior) is confidently related with followers' satisfaction of public schools in the western part of Germany. Therefore, referred to those prior empirical findings, the first proposed hypothesis is: 
$\boldsymbol{H}_{I}:$ Transactional leadership positively influences job satisfaction.

Similar to the relationship between transactional leadership and job satisfaction, prior empirical findings disclosed a critical relationship between visionary (transformational) leadership and job fulfillment (Bartram \& Casimir, 2007; Kara et al., 2013; Yaghoubipoor et al., 2013). At least, there are three noteworthy empirical findings related to the connection of transformative management and employees' job satisfaction. Firstly, the research of Bartram and Casimir (2007), which employed 150 client-service administrators in an Australian callcenter as the sample, found the important and direct effect of the visionary and inspiring leaders on employees' job satisfaction. Secondly, the same positive effect happened to hotel employees' perceived QWL (quality of work life) when transformative leadership took place (Kara et al., 2013). They argue that managers' leadership styles in the workplace will be essentially influencing the employee outcomes, resulting in the higher of employee's commitment, productivity, and satisfaction in many aspects, such as in the work-life and non-work life domains, and even in their overall life (Sirgy et al., 2001). Thirdly, the study of Yaghoubipoor et al. (2013) identified a unique conclusive relationship between managers' transformative administration styles as perceived by their aides and the stage of worker's job fulfillment in the Iranian automotive industry. Furthermore, transformative managers encourage their subordinates to achieve the higher dignity and self-encompassment (Bass, 1985). Those supervisors usually show their deep concern to subordinate's needs and create a sense of shared courage (Jung et al., 2008). It is to stimulate their team members to be more inventive and ingenious in their problem-solving. Therefore, referred to those prior empirical findings, the second proposed hypothesis is:

$\boldsymbol{H}_{2}:$ Transformational leadership positively influences job satisfaction.

Understanding the employee's job satisfaction is one of the critical things for the success of the business because it leads to a customer satisfaction (Jung and Yoon, 2013). The more fulfilled laborers associate with, the more substantial amount of satisfied customer. This statement means that it is rare to find a contradictory relationship between these two variables (Wangenheim et al., 2007; Chi \& Gursoy, 2009; Jung \& Yoon, 2013; Pantouvakis \& Bouranta, 2013; Eren et al., 2013; Mahmoud \& Reisel, 2014; Hur et al., 2015). The research of Hur et al. (2015), which empirically tested the employee's job satisfaction in a South Korean home care provider, found a significant and positive effect on customer satisfaction. This finding revealed that highly satisfied service-employees would produce pleasing mood leading to favorable customers' service quality evaluation. Similarly, there is a positive link between employee-customer satisfaction at the family restaurant in Seoul. Furthermore, satisfied employees, who work more productively, will affect positively and significant on customer satisfaction. Pantouvakis and Bouranta (2013) believe that satisfied employees are to be more encouraged, enabled, caring and involved to firm's goals and also customer desires. Therefore, derived from those empirical findings and relevant theories, the third proposed hypothesis is:

$\boldsymbol{H}_{3}$ : Employee's job satisfaction positively influences customer satisfaction.

The basis of real customer loyalty is customer satisfaction. Many organizations are attempting to make their customer feel satisfied because creating customer loyalty is more profitable and efficient than obtaining and enticing new customer (Song et al., 2011). Many studies have discussed and proved the relationship between those two variables successfully (Chen \& Tsai, 2008; Ladhari et al., 2008; Liu \& Jang, 2009; Yoon et al., 2010; Christodoulides \& Michaelidou, 2011; Dolnicar et al., 2011; Picon et al., 2014). For example, the research of Picon et al. (2014) supports the connection between satisfaction-loyalty of 785 customers from 74 insurance companies in the service sector. In the context of e-commerce sector, Christodoulides and Michaelidou (2011) showed the similar finding that there was the positive effect of e-satisfaction on e-loyalty. Also, the related study of Ladhari et al. (2008) shows that customer loyalty correlates positively with his or her satisfaction levels. Furthermore, those several previous studies concluded explicitly that the more the customers were satisfied, the longer they were loyal. Nevertheless, if customers feel dissatisfied with the service they have received, they were unlikely to utilize the same service providers, then they will move or switch their choice to the other providers. Therefore, based on those arguments, the fourth hypothesis is:

\section{$\boldsymbol{H}_{4}:$ Customer satisfaction positively influences customer loyalty.}

There are four proposed hypotheses that can be summarized in the following research model (Figure 1). 


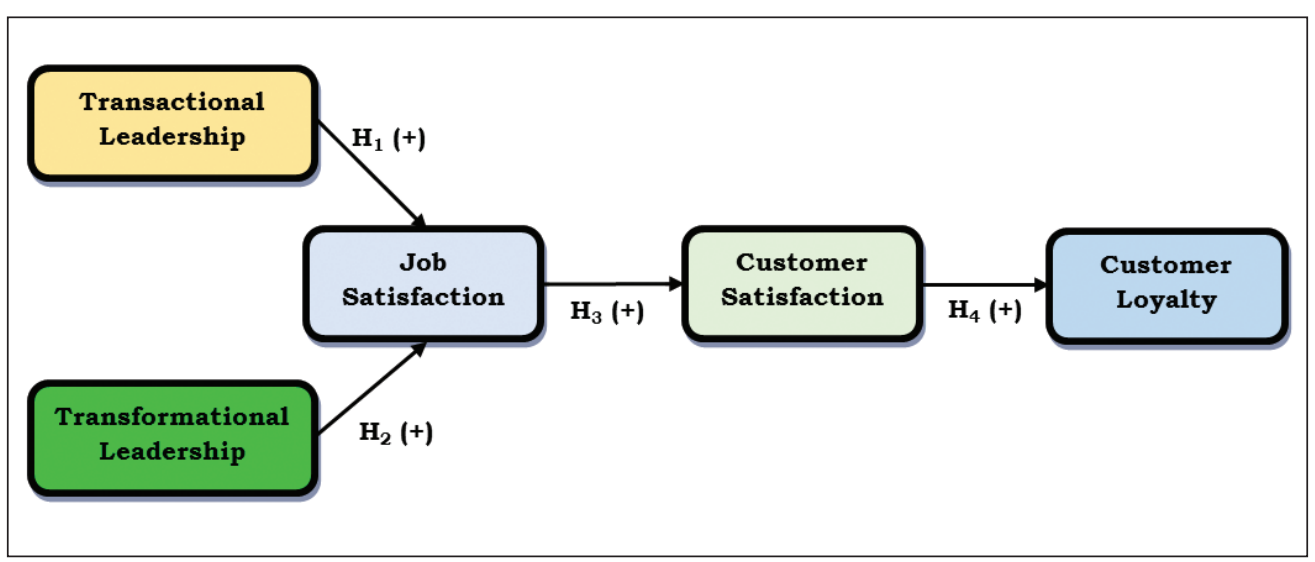

Figure 1: Research Model

\section{Research Methods and Materials}

This study employed 160 front liners (flight attendants, reservation/ticketing, and check-in-counter officers) who worked in Branch Office/General Sales Agent of Indonesian commercial airlines. Those airlines are Garuda Indonesia, Merpati Nusantara Airlines, Mandala Airlines, Indonesia Air Asia, Lion Air, Wings Air, Sriwijaya Air, Kalstar Aviation, Express Air, Citilink, Trans Nusa, Batik Air, Susi Air, Aviastar, and Sky Aviation. The studied airlines serve domestic routes based at Soekarno-Hatta International Airport. The front liners responded to the distributed questionnaires to find out whether Indonesia's airline industry fully implemented the transactional and transformational leadership or not. It also asked those staffs to respond to the questions, whether those kinds of leadership affected the needed employees' job satisfaction to produce the highest quality of customer service, please, and maintain the loyalty of its customer or not.

In this study, transactional and transformational leadership are independent variables. There are job satisfaction and customer satisfaction as intervening/mediating variables, and customer loyalty for the dependent variable. The dimensions of each variable will be mentioned in the following table.

This study adopted the work of Sarros and Santora (2001) in developing the dimension and constructs of transactional and transformational leadership, the works of Wagner and Hollenbeck (2010) and Pantouvakis and Bouranta (2013) in defining the dimensions and constructs of job satisfaction. For the customer satisfaction's dimensions and constructs, this study employed the research of Zeithaml et al. (2006) and $\mathrm{Ha}$ et al. (2011). Meanwhile, to measure the customer loyalty, the developed questionnaire used the research of Oliver (1999) and Yang and Peterson (2004).
The correlation of independent variables, i.e., transactional and transformational leadership, shows that there is free of multicollinearity, due to the value $(0.587)$ is less than the maximum value (0.80), which indicates the presence of multicollinearity (Gujarati, 1995). The correlation between both of leadership styles with job satisfaction is significant and positive. It implies an increase of those leadership styles will increase employees' job satisfaction. Furthermore, the relationship between job satisfaction and customer satisfaction shows a considerable likelihood for an employee to provide an excellent service to their customer if they are already satisfied with their job/company. Moreover, the loyalty of customer will also increase if they feel satisfied with the service, as shown by the positive and significant correlation between customer satisfaction and customer loyalty, as described in Table 2.

This study used factor analysis to test each construct's validity and the estimation of reliability (alpha) of each variable (see Table 3). The Tabachnick and Fidell's (1996) technique became the standard for factor analysis process until there were no invalid statement-items according to the criteria set out in SPSS 20 and its factor loading was equal to or higher than 0.5 . This study used the Cronbach's Alpa to test the consistency of the overall respondents in answering the statement-items of a particular variable (i.e., to examine the variable reliability). The Cronbach's Alpha value should be commonly bigger than 0.6 (Hair et al., 2006). The higher value of Cronbach's Alpha is the better reliability of the variables. From validity test, there are seven invalid items: two items of transactional leadership (CR3 and AM3); one item of transformational leadership (II3); two items of customer satisfaction (SQ5 and PC2); and two items of customer loyalty (CG4 and AT1), while other constructs are reliable. 
Table 1: The Variable's Dimensions

\begin{tabular}{|c|c|c|c|}
\hline Variable & & Dimension & Total of Statement \\
\hline $\begin{array}{l}\text { Transactional Leadership } \\
\left(\mathrm{X}_{1}\right)\end{array}$ & $\begin{array}{l}\text { CR } \\
\text { AM } \\
\text { PM } \\
\text { LF }\end{array}$ & $\begin{array}{l}\text { Contingent Reward } \\
\text { Active Management by Exception } \\
\text { Passive Management by Exception } \\
\text { Laissez Faire }\end{array}$ & $\begin{array}{l}3 \text { items } \\
3 \text { items } \\
4 \text { items } \\
4 \text { items }\end{array}$ \\
\hline $\begin{array}{l}\text { Transformational } \\
\text { Leadership } \\
\left(\mathrm{X}_{2}\right)\end{array}$ & $\begin{array}{l}\text { II } \\
\text { IM } \\
\text { IS }\end{array}$ & $\begin{array}{l}\text { Idealized Influence } \\
\text { Inspirational Motivation } \\
\text { Intellectual Stimulation } \\
\text { Individual Consideration }\end{array}$ & $\begin{array}{l}6 \text { items } \\
7 \text { items } \\
9 \text { items } \\
8 \text { items }\end{array}$ \\
\hline $\begin{array}{l}\text { Job } \\
\text { Satisfaction } \\
\left(Y_{1}\right)\end{array}$ & $\begin{array}{l}\text { AC } \\
\text { CO } \\
\text { IN } \\
\text { RE } \\
\text { SS } \\
\text { ST }\end{array}$ & $\begin{array}{l}\text { Activity } \\
\text { Compensation } \\
\text { Independence } \\
\text { Recognition } \\
\text { Social Service } \\
\text { Social Status }\end{array}$ & $\begin{array}{l}4 \text { items } \\
4 \text { items } \\
4 \text { items } \\
4 \text { items } \\
4 \text { items } \\
5 \text { items }\end{array}$ \\
\hline $\begin{array}{l}\text { Customer Satisfaction } \\
\left(\mathrm{Y}_{2}\right)\end{array}$ & $\begin{array}{l}S Q \\
P Q \\
P C \\
P F \\
\text { SF }\end{array}$ & $\begin{array}{l}\text { Service Quality } \\
\text { Product Quality } \\
\text { Price } \\
\text { Personal Factors } \\
\text { Situational Factors }\end{array}$ & $\begin{array}{l}6 \text { items } \\
4 \text { items } \\
4 \text { items } \\
3 \text { items } \\
6 \text { items }\end{array}$ \\
\hline $\begin{array}{l}\text { Customer Loyalty } \\
\text { (Z) }\end{array}$ & $\begin{array}{l}\text { CG } \\
\text { AT } \\
\text { CT } \\
\text { AC }\end{array}$ & $\begin{array}{l}\text { Cognitive Loyalty } \\
\text { Affective Loyalty } \\
\text { Conative Loyalty } \\
\text { Action Loyalty }\end{array}$ & $\begin{array}{l}4 \text { items } \\
4 \text { items } \\
3 \text { items } \\
3 \text { items }\end{array}$ \\
\hline
\end{tabular}

Table 2: Inter-correlations

\begin{tabular}{|l|c|c|c|c|c|c|c|}
\hline Constructs & Mean & Std.Dev. & $\mathbf{( 1 )}$ & $\mathbf{( 2 )}$ & $\mathbf{( 3 )}$ & $\mathbf{( 4 )}$ & $\mathbf{( 5 )}$ \\
\hline TCL & 4.18 & 0.811 & 1 & - & - & - & - \\
\hline TFL & 4.79 & 0.659 & $0.587^{* *}$ & 1 & - & - & - \\
\hline JS & 4.35 & 0.667 & $0.750^{* *}$ & $0.656^{* *}$ & 1 & - & - \\
\hline CS & 4.22 & 0.532 & $0.645^{* *}$ & $0.630^{* *}$ & $0.730^{* *}$ & 1 & - \\
\hline CL & 4.13 & 0.689 & $0.630^{* *}$ & $0.639^{* *}$ & $0.733^{* *}$ & $0.873^{* *}$ & 1 \\
\hline
\end{tabular}

Note: ${ }^{* * *} p<0.001 ;{ }^{* *} p<0.01 ;{ }^{*} p<0.05 ; \mathrm{TCL}=$ transactional leadership; TFL = transformational leadership; JS = job satisfaction; $\mathrm{CS}=$ customer satisfaction; $\mathrm{CL}=$ customer loyalty 
Mohamad RIZAN, Ari WAROKKA, Agus WIBOWO, Ika FEBRILIA /

Table 3: Test of Construct's Validity and Reliability

\begin{tabular}{|c|c|c|c|c|c|}
\hline Construct & Item & Factor Loading & Item & Factor Loading & Cronbach Alpha \\
\hline \multirow[t]{6}{*}{ Transactional Leadership } & CR1 & 0.668 & PM3 & 0.660 & \multirow{6}{*}{0.903} \\
\hline & CR2 & 0.681 & PM4 & 0.607 & \\
\hline & AM1 & 0.732 & LF1 & 0.778 & \\
\hline & AM2 & 0.781 & LF2 & 0.824 & \\
\hline & PM1 & 0.548 & LF3 & 0.820 & \\
\hline & PM2 & 0.520 & LF4 & 0.793 & \\
\hline \multirow{15}{*}{$\begin{array}{l}\text { Transformational } \\
\text { Leadership }\end{array}$} & II1 & 0.556 & IS3 & 0.714 & \multirow{15}{*}{0.968} \\
\hline & 112 & 0.745 & IS4 & 0.789 & \\
\hline & 114 & 0.654 & IS5 & 0.713 & \\
\hline & 115 & 0.667 & IS6 & 0.796 & \\
\hline & 116 & 0.665 & IS7 & 0.800 & \\
\hline & IM1 & 0.788 & IS8 & 0.819 & \\
\hline & $\mathrm{IM} 2$ & 0.822 & IS9 & 0.770 & \\
\hline & IM3 & 0.823 & IC1 & 0.741 & \\
\hline & IM4 & 0.705 & IC2 & 0.775 & \\
\hline & IM5 & 0.805 & IC3 & 0.570 & \\
\hline & IM6 & 0.849 & IC4 & 0.744 & \\
\hline & IM7 & 0.767 & IC5 & 0.754 & \\
\hline & IS1 & 0.652 & IC6 & 0.544 & \\
\hline & IS2 & 0.631 & IC7 & 0.779 & \\
\hline & & & IC8 & 0.800 & \\
\hline \multirow[t]{13}{*}{ Job Satisfaction } & AC1 & 0.659 & RE1 & 0.653 & \multirow{13}{*}{0.968} \\
\hline & $\mathrm{AC2}$ & 0.814 & RE2 & 0.691 & \\
\hline & AC3 & 0.837 & RE3 & 0.695 & \\
\hline & $\mathrm{AC4}$ & 0.725 & RE4 & 0.655 & \\
\hline & $\mathrm{CO} 1$ & 0.786 & SS1 & 0.763 & \\
\hline & $\mathrm{CO} 2$ & 0.791 & SS2 & 0.753 & \\
\hline & $\mathrm{CO} 3$ & 0.746 & SS3 & 0.842 & \\
\hline & $\mathrm{CO} 4$ & 0.717 & SS4 & 0.799 & \\
\hline & IN1 & 0.790 & ST1 & 0.773 & \\
\hline & IN2 & 0.827 & ST2 & 0.787 & \\
\hline & IN3 & 0.804 & ST3 & 0.755 & \\
\hline & IN4 & 0.764 & ST4 & 0.767 & \\
\hline & & & ST5 & 0.783 & \\
\hline \multirow[t]{11}{*}{ Customer Satisfaction } & SQ1 & 0.719 & PC3 & 0.777 & \multirow{11}{*}{0.949} \\
\hline & SQ2 & 0.766 & PC4 & 0.764 & \\
\hline & SQ3 & 0.651 & PF1 & 0.751 & \\
\hline & SQ4 & 0.615 & PF2 & 0.551 & \\
\hline & SQ6 & 0.682 & PF3 & 0.704 & \\
\hline & PQ1 & 0.756 & SF1 & 0.654 & \\
\hline & PQ2 & 0.865 & SF2 & 0.778 & \\
\hline & PQ3 & 0.852 & SF3 & 0.689 & \\
\hline & PQ4 & 0.756 & SF4 & 0.662 & \\
\hline & PC1 & 0.733 & SF5 & 0.540 & \\
\hline & & & SF6 & 0.637 & \\
\hline \multirow[t]{6}{*}{ Customer Loyalty } & CG1 & 0.646 & CT1 & 0.708 & \multirow{6}{*}{0.925} \\
\hline & CG2 & 0.650 & CT2 & 0.757 & \\
\hline & CG3 & 0.773 & CT3 & 0.771 & \\
\hline & AT2 & 0.782 & AC1 & 0.797 & \\
\hline & AT3 & 0.802 & $\mathrm{AC2}$ & 0.834 & \\
\hline & AT4 & 0.735 & AC3 & 0.714 & \\
\hline
\end{tabular}


Table 4: Fit Indices for the Measurement Model

\begin{tabular}{|l|c|c|l|}
\hline Fit Index & This Study & Recommended Values & \multicolumn{1}{c|}{ Source } \\
\hline Df & 6 & & \\
\hline $\mathrm{X}^{2}$ & 81.431 & & \\
\hline $\mathrm{X}^{2} / \mathrm{df}$ & 13.572 & $\leq 3.00$ & Gefen et al. (2000) \\
\hline GFI & 0.849 & $\geq 0.90$ & Hoyle (1995) \\
\hline AGFI & 0.622 & $\geq 0.80$ & Chau \& Hu (2001) \\
\hline CFI & 0.871 & $\geq 0.90$ & Bagozzi \& Yi (1988) \\
\hline RMSEA & 0.281 & $\leq 0.08$ & Browne \& Cudeck (1993) \\
\hline TLI & 0.785 & $\geq 0.90$ & Bagozzi \& Yi (1988) \\
\hline RMR & 0.071 & $\leq 0.08$ & Arbuckle (2005) \\
\hline NFI & 0.863 & $\geq 0.90$ & Hair et al. (1998) \\
\hline
\end{tabular}

\section{Results and Discussion}

Figure 2 indicates the results of four hypotheses testing. The test of the first hypothesis describes the positive influence of transactional leadership on job satisfaction $(\beta=0.674$; $\mathrm{p}<0.001)$. The result supports the works of Yammarino et al. (1998), Walumbwa et al. (2008), Pihie et al. (2011), Ewen et al. (2013), and Doan et al. (2020). In other words, the front-liners in airline's industry in Indonesia are more motivated by transactional style, which is applied by their leader in the workplace. Obviously, contingent reward as a stimulation tool from their employer gives high influence to the subordinates to achieve their excellent performance.

This finding is similar to the acceptance of second hypothesis $(\beta=0.391 ; \mathrm{p}<0.001)$, which shows the positive and significant relationship between transformational leadership on job satisfaction. It is in line with the previous studies by Bartram and Casimir (2007), Kara et al. (2013), and Yaghoubipoor et al. (2013). Furthermore, this result reveals that reward is not the only driving thing that could stimulate the front-liners to do their job well. It also provides the opportunity to share their vision, the challenge for problem-solving, and the emotional connection between leader-subordinate that is developed by trust and confidence. Moreover, those efforts, which are implemented by a transformational leader, drive the subordinates to be more creative and innovative to fulfill their job responsibility and be more satisfied with completing it. However, regarding the Indonesian frontliners case, the transformative leadership effect on job satisfaction is lower than the transactional one.

For the third hypothesis, the result shows that job satisfaction does affect customer satisfaction $(\beta=0.776$; $\mathrm{p}<0.001)$. It supports the prior studies of Wangenheim et al. (2007), Chi and Gursoy (2009), Jung and Yoon (2013),
Pantouvakis and Bouranta (2013), Eren et al. (2013), Mahmoud and Reisel (2014), and Hur et al. (2015). This relationship currently describes that the front-liners, which are satisfied by their performance in the workplace, would share their positive mood and be more caring to the customer, especially airline's passenger in this case. Also, the frontliners perceive their job responsibility to serve the customer as the engaging and challenging task that must be completed well, to support the organization's goals.

Similarly, the fourth hypothesis also demonstrates that customer satisfaction has a positive and significant effect on customer loyalty $(\beta=0.933 ; \mathrm{p}<0.001)$. This finding equals with the previous researches by Chen and Tsai (2008), Ladhari et al. (2008), Liu and Jang (2009), Yoon et al. (2010), Christodoulides and Michaelidou (2011), Dolnicar et al. (2011), and Picon et al. (2014). It also implies that as the satisfaction of customer about service in airlines increased, then the intention to repurchase and become a loyal customer would also upsurge.

Meanwhile, the mediating effect's tests show three important findings. First, job satisfaction performs a partial mediating effect in the relationship between transactional leadership and customer satisfaction. The indirect effect is $0.299(0.674 \times 0.444)$, bigger than the direct one of the transactional leadership on customer satisfaction (0.222). The study applied the Sobel test (Preacher \& Leonardelli, 2003) to examine the mediating effect significance of job satisfaction. The result was significant $(z=4.038$ and $\mathrm{p}<$ 0.01 ) as shown in Table 5. It implies that job satisfaction performs a mediating variable for a manager-subordinate exchange-based leadership and customer satisfaction, inwhich manager exchange rewards or punishment with the subordinates for the task performed, and in return presumes productivity, efforts, employee loyalty, and the satisfied customer (Naidu \& van der Walt, 2005). 


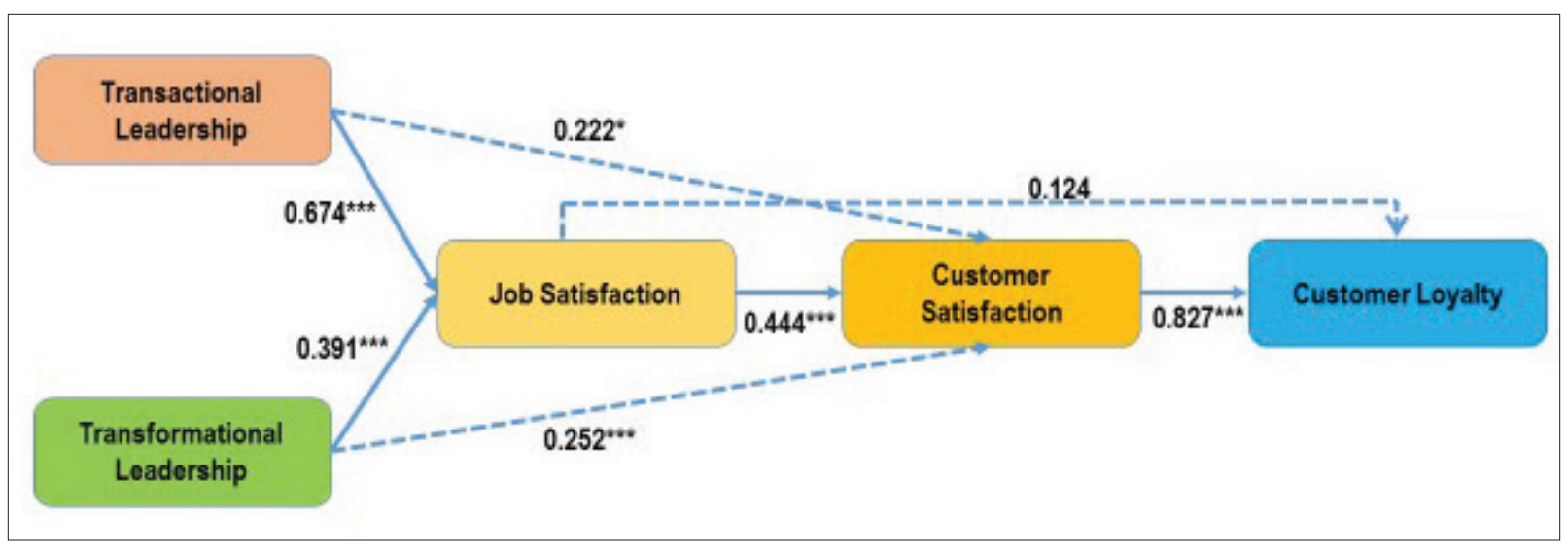

Note: ${ }^{* * *} p<0.001{ }^{* *} p<0.01{ }^{*} p<0.05$

Figure 2: Hypotheses Testing

Table 5: Mediator Test of Job Satisfaction between Transactional Leadership-Customer Satisfaction

\begin{tabular}{|l|l|c|c|c|}
\hline Model & \multicolumn{1}{|c|}{ Relationships } & Standardised Estimate (Rc) & $\mathbf{C r}$ & Sobel Test \\
\hline 1 & Transactional Leadership - Customer Satisfaction & $0.521^{* *}$ & 4.038 & Supported \\
\hline 2 & Transactional Leadership - Job Satisfaction & $0.674^{* *}$ & 11.585 & \\
\hline & Transactional Leadership - Customer Satisfaction & $0.222^{*}$ & 2.292 & \\
\hline & Job Satisfaction - Customer Satisfaction & $0.444^{* *}$ & 4.291 & \\
\hline
\end{tabular}

Note: ${ }^{*} p<0.05 ;{ }^{*} p<0.01$ (one-tailed test)

Table 6: Mediator Test of Job Satisfaction between Transformational Leadership-Customer Satisfaction

\begin{tabular}{|l|l|c|c|c|}
\hline Model & \multicolumn{1}{|c|}{ Relationships } & Standardised Estimate (Rc) & Cr & Sobel Test \\
\hline 1 & Transformational Leadership - Customer Satisfaction & $0.426^{\star *}$ & 3.675 & Supported \\
\hline 2 & Transformational Leadership - Job Satisfaction & $0.391^{* *}$ & 7.013 & \\
\hline & Transformational Leadership - Customer Satisfaction & $0.252^{* *}$ & 3.496 & \\
\hline & Job Satisfaction - Customer Satisfaction & $0.444^{* *}$ & 4.291 & \\
\hline
\end{tabular}

Note: ${ }^{*} p<0.05 ;{ }^{* *} p<0.01$ (one-tailed test)

Second, the relationship between transformational leadership and customer satisfaction was partially mediated by job satisfaction. The indirect effect is $0.173(0.391 \mathrm{x}$ $0.444)$, lower than the transformational leadership's direct effect on customer satisfaction (0.252). By applying the Sobel test (Preacher \& Leonardelli, 2003) to measure whether the job satisfaction's mediating effect was significant or not, the result was substantial $(\mathrm{z}=3.675$ and $\mathrm{p}<0.01)$ as shown in Table 6. Even though the effect of inspired and engaged leader-employee relationship on customer satisfaction was mediated by subordinates' job satisfaction, which is reflected in their appreciation, decisive work fulfillment, and higher organizational outcomes (Givens, 2008; Berson \& Avolio, 2004), its direct effect was quite considerable. It implies that at the time the transformative leaders empower, respect and trust their employee to be productive, innovative, and perform optimally; consequently, those engagements will elevate customer satisfaction (Konczak et al., 2000; Namasivayam et al., 2014; Srivastava et al., 2006).

Third, the relationship between job satisfaction and customer loyalty was fully mediated by customer satisfaction. The indirect effect is 0.367 ( $0.444 \times 0.827)$, bigger than the job satisfaction's direct effect on customer loyalty $(0.124)$. The Sobel's mediating effect test (Preacher \& Leonardelli, 2003) revealed that the influence was significant $(z=4.067$ and $p<0.01)$ as shown in Table 7. It implies that any companies or organizations want to achieve customer loyalty, they should build customer satisfaction first. The unsatisfied employees, specifically with their positions, are a great hurdle to develop customer loyalty (Ahearne et al., 2005; Gazzoli et al., 2010). 
Table 7: Mediator Test of Customer Satisfaction between Job Satisfaction-Customer Loyalty

\begin{tabular}{|l|l|c|c|c|}
\hline Model & \multicolumn{1}{|c|}{ Relationships } & Standardised Estimate (Rc) & $\mathbf{C r}$ & Sobel Test \\
\hline 1 & Job Satisfaction - Customer Loyalty & $0.491^{* *}$ & 4.067 & Supported \\
\hline 2 & Job Satisfaction - Customer Satisfaction & $0.444^{* *}$ & 4.291 & \\
\hline & Job Satisfaction - Customer Loyalty & 0.124 & 0.060 & \\
\hline & Customer Satisfaction - Customer Loyalty & $0.827^{* *}$ & 12.379 & \\
\hline
\end{tabular}

Note: ${ }^{*} p<0.05 ;{ }^{*} p<0.01$ (one-tailed test)

In other words, the disgruntled subordinates produce a big negative energy flowing through the company, which finally the objective to become a high-performance organization, in which customer loyalty is one of the indicators, will never be achieved (Malhotra \& Mukherjee, 2004). Therefore, it is important to determine the cause of the employees' dissatisfaction, especially those who are dealing daily with the external customers (Gill \& Mathur, 2007).

\section{Conclusions}

This study examines the influences of transactional leadership and transformational leadership on job satisfaction, customer satisfaction, and customer loyalty. By using a sample of 160 front-liners of several airlines in Indonesia and proposing the four hypotheses, this current study proposes some critical results. Both of transactional and transformational leadership significantly influenced the employees' job satisfaction. The transactional leader usually implements contingent reward while the transformational leader is stimulated their subordinates by developing the emotional relationship, to achieve the high level of subordinate's performance. Furthermore, now many organizations are focusing on satisfying their customer by motivating their subordinate, because maintaining the exist customer is profitable than creating new customer.

This study also finds the mediating effect of job satisfaction in both leadership styles (transformational and transactional leadership) and customer satisfaction. This intervening influence is significant. It partially mediates the effect of manager-subordinate exchange-based leadership and transformative leadership on passenger satisfaction. It affirms the idea of creating employee satisfaction, firstly, through a suitable leadership style to achieve customer satisfaction. It also finds that customer satisfaction performs a full intervening role in the relationship between job satisfaction and customer loyalty. It confirms the idea of satisfying the company's internal customer (employee) to encourage subordinates' positive performance, which in turn yield customer satisfaction and build customer loyalty.
This research has several limitations, such as a limited number of frontline employees used, a cross-sectional study, and a specific airline industry, which it restricts the generalization of the findings. However, at the same time, it provides some research-extension possibilities, such as acquiring a large sample from other countries' airline industry, a longitudinal study to explore the consistency effect, and a comparison from similar service-sector industries (e.g., healthcare industry, hospitality industry, higher-education sector, and public service).

\section{References}

Ahearne, M., Mathieu, J., \& Rapp, A. (2005). To empower or not to empower your sales force? An empirical examination of the influence of leadership empowerment behavior on customer satisfaction and performance. Journal of Applied Psychology, 90(5), 945-955.

Arbuckle, J. L. (2005). AMOS 6.0 user's guide. Crawfordville, FL: AMOS Development Corp.

Bagozzi, R. P., \& Yi, Y. (1988). On the evaluation of structural equation models. Journal of the Academy of Marketing Science, 16(1), 74-94.

Bartram, T., \& Casimir, G. (2007). The relationship between leadership and follower in-role performance and satisfaction with the leader: The mediating effects of empowerment and trust in the leader. Leadership and Organization Development Journal, 28(1), 4-19.

Bass, B. M. (1985). Leadership and performance: Beyond expectations. New York, NY: The Free Press.

Berson, Y., \& Avolio, B. J. (2004). Transformational leadership and the dissemination of organizational goals: A case study of a telecommunication firm. The Leadership Quarterly, 15(5), 625-646.

Bono, J. E., \& Judge, T. A. (2004). Personality and transformational and transactional leadership: A meta-analysis. Journal of Applied Psychology, 89(5), 901-910.

Browne, M. W., \& Cudeck, R. (1993). Alternative ways of assessing model fit. In: K. A. Bollen \& J. S. Long (Eds.), Testing Structural Equation Models (pp. 136-162). Newbury Park, CA: Sage Publications.

Burns, J. M. (1978). Leadership. New York, NY: Harper \& Row. 
Chau, P. Y. K., \& Hu, P. (2001). Information technology acceptance by individual professionals: A model comparison approach. Decision Sciences, 32(4), 699-719.

Chen, C. F., \& Tsai, M. H. (2008). Perceived value, satisfaction, and loyalty of TV travel product shopping: Involvement as a moderator. Tourism Management, 29(6), 1166-1171.

Chi, C. G., \& Gursoy, D. (2009). Employee satisfaction, customer satisfaction, and financial performance: An empirical examination. International Journal of Hospitality Management, 28(2), 245-253.

Christodoulides, G., \& Michaelidou, N. (2011). Shopping motives as antecedents of e-satisfaction and e-loyalty. Journal of Marketing Management, 27(1/2), 181-197.

Doan, T. T. T., Nguyen, L. C. T., \& Nguyen, T. D. N. (2020). Emotional Intelligence and Project Success: The Roles of Transformational Leadership and Organizational Commitment. Journal of Asian Finance, Economics and Business, 7(3), 223-233. https://doi.org/10.13106/jafeb.2020.vol7.no3.223

Dolnicar, S., Grabler, K., Grun, B., \& Kulnig, A. (2011). Key drivers of airline loyalty. Tourism Management, 32(5), 1020-1026.

Emsina, A. A. (2014). Labour productivity, economic growth and global competitiveness in post-crisis period. Procedia - Social and Behavioral Sciences, 156, 317-321.

Eren, S. S., Eren, M. S., Ayas, N., \& Hacioglu, G. (2013). The effect of service orientation on financial performance: The mediating role of job satisfaction and customer satisfaction. ProcediaSocial and Behavioral Sciences, 99, 665-672.

Ewen, C., Wihler, A., Blickle, G., Oerder, K., Ellen III, B. P. E., Douglas, C., \& Ferris, G. R. (2013). Further specification of the leader political skill-leadership effectiveness relationships: Transformational and transactional leader behavior as mediators. The Leadership Quarterly, 24(4), 516-533.

Gazzoli, G., Hancer, M., \& Park, Y. (2010). The role and effect of job satisfaction and empowerment on customers' perception of service quality: A study in the restaurant industry. Journal of Hospitality and Tourism Research, 34(1), 56-77.

Gefen, D., Straub, D., \& Boudreau, M. C. (2000). Structural equation modeling and regression: Guidelines for research practice. Communications of the Association for Information Systems, 4(7), 1-70.

Gill, A. S., \& Mathur, N. (2007). Improving employee dedication and pro-social behavior. International Journal of Contemporary Hospitality Management, 19(4), 328-334.

Givens, R. (2008). Transformational leadership: The impact on organizational and personal outcomes. Emerging Leadership Journeys, 1(1), 4-24.

Gujarati, D. N. (1995). Basic econometrics. New York, NY: McGraw-Hill.

Ha, H. Y., John, J., Janda, S., \& Muthaly, S. (2011). The effects of advertising spending on brand loyalty in services. European Journal of Marketing, 45(4), 673-691.
Hair, J. F. Jr., Anderson, R. E., Tatham, R. L., \& Black, W. C. (1998). Multivariate data analysis (5th Ed.). Upper Saddle River, NJ: Prentice Hall.

Hair, J. F. Jr., Anderson, R. E., Tatham, R. L., \& Black, W. C. (2006). Multivariate data analysis (6th Ed.). Upper Saddle River, NJ: Prentice Hall.

Hoyle, R. H. (1995). Structural equation modeling. Thousand Oaks, CA: Sage Publications, Inc.

Hur, W. M., Moon, T. W., \& Jung, Y. S. (2015). Customer response to employee emotional labor: The structural relationship between emotional labor, job satisfaction, and customer satisfaction. Journal of Services Marketing, 29(1), 71-80.

Ivancevich, J., Olelelns, M., \& Matterson, M. (1997). Organizational behavior and management. Sydney, Australia: Irwin.

Judge, T. A., \& Piccolo, R. F. (2004). Transformational and transactional leadership: A meta-analytic test of their relative validity. Journal of Applied Psychology, 89(5), 755-768.

Jung, D., Wu, A., \& Chow, C. W. (2008). Towards understanding the direct and indirect effects of CEOs' transformational leadership on firm innovation. The Leadership Quarterly, 19(5), 582-594.

Jung, H. S., \& Yoon, H. H. (2013). Do employees' satisfied customers respond with a satisfactory relationship? The effects of employees' satisfaction on customers' satisfaction and loyalty in a family restaurant. International Journal of Hospitality Management, 34(1), 1-8.

Kara, D., Uysal, M., Sirgy, M. J., \& Lee, G. (2013). The effects of leadership style on employee well-being in hospitality. International Journal of Hospitality Management, 34(1), 9-18.

Krishnan, V. R. (2012). Transformational leadership and personal outcomes: empowerment as mediator. Leadership \& Organization Development Journal, 33(6), 550 - 563.

Konczak, L. J., Stelly, D. J., \& Trusty, M. L. (2000). Defining and measuring empowering leader behaviors: development of an upward feedback instrument. Educational and Psychological Measurement, 60(2), 301-312.

Kotler, P. (2001). A framework for marketing management. Upper Saddle River, NJ: Prentice Hall.

Ladhari, R., Brun, I., \& Morales, M. (2008). Determinants of dining satisfaction and post-dining behavioral intentions. International Journal of Hospitality Management, 27(4), 563-573.

Liu, Y., \& Jang, S. C. (2009). Perceptions of Chinese restaurants in the U.S.: What affects customer satisfaction and behavioral intentions? International Journal of Hospitality Management, 28(3), 338-348.

Locke, E. A. (1969). What is job satisfaction? Organizational Behavior and Human Performance, 4(4), 309-336.

Mahmoud, A. B., \& Reisel, W. D. (2014). Relating patient satisfaction to nurses' job satisfaction, job security, and obedience OCBs. International Journal of Pharmaceutical and Healthcare Marketing, 8(1), 47-61. 
Malhotra, N., \& Mukherjee, A. (2004). The relative influence of organizational commitment and job satisfaction on service quality of customer-contact employees in banking call centers. Journal of Services Marketing, 18(3), 162-174.

Menon, M. E. (2014). The relationship between transformational leadership, perceived leader effectiveness and teachers' job satisfaction. Journal of Educational Administration, 52(4), 509-528.

Naidu, J., \& van der Walt, M.S. (2005). An exploration of the relationship between leadership styles and the implementation of transformation interventions. SA Journal of Human Resource Management, 3(2), 1-10.

Namasivayam, K., Guchait, P., \& Lei, P. (2014). The influence of leader empowering behaviors and employee psychological empowerment on customer satisfaction. International Journal of Contemporary Hospitality Management, 26(1), 69-84.

Oliver, R. L. (1999). Whence consumer loyalty? Journal of Marketing, 63(4), 33-44.

Pantouvakis, A., \& Bouranta, N. (2013). The interrelationship between service features, job satisfaction and customer satisfaction. The TQM Journal, 25(2), 186-201.

Picon, A., Castro, I., \& Roldan, J. L. (2014). The relationship between satisfaction and loyalty: A mediator analysis. Journal of Business Research, 67(5), 746-751.

Pihie, Z. A. L., Sadeghi, A., \& Elias, H. (2011). Analysis of head of departments leadership styles: Implication for improving research university management practices. Procedia - Social and Behavioral Sciences, 29, 1081-1090.

Preacher, K. J., \& Leonardelli, G. J. (2003). Calculation for the Sobel test: An interactive calculation tool for mediation tests. Retrieved November 30, 2019, from: http://people. ku.edu/ preacher/sobel/sobel.htm.

Sarros, J. C., \& Santora, J. C. (2001). The transformationaltransactional leadership model in practice. Leadership \& Organization Development Journal, 22(8), 383-393.

Sirgy, M. J., Efraty, D., Siegel, P., \& Lee, D. (2001). A new measure of quality of work life (QWL) based on need satisfaction and spillover theories. Social Indicators Research, 55(3), 241-302.

Song, H., Veen, R., Li, G., \& Chen, J. L. (2011). The Hong Kong tourist satisfaction index. Annals of Tourism Research, 39(1), 459-479.

Spector, P. E. (1997). Job satisfaction: Application, assessment, causes and consequences. Thousand Oaks, CA: Sage Publications.

Srivastava, A., Bartol, K. M., \& Locke, E. A. (2006). Empowering leadership in management teams: effects on knowledge sharing, efficacy, and performance. Academy of Management Journal, 49(6), 1239-1251.

Suparno., Wibowo, A., Mukhtar, S., Narmaditya, B. S., \& Sinta, H. D. (2019). The Determinant Factors of Development Batik Cluster Business: Lesson from Pekalongan, Indonesia. Journal of Asian Finance, Economics and Business, 6(4), 227-233. https://doi.org/10.13106/jafeb.2019.vol6.no4.227

Tabachnick, B. G., \& Fidell, L.S. (1996). Using multivariate statistics. New York, NY: HarperCollins College Publishers.

Tran, D.-T., Lee, L.-Y., Nguyen, P.-T., \& Srisittiratkul, W. (2020). How Leader Characteristics and Leader Member Exchange Lead to Social Capital and Job Performance. Journal of Asian Finance, Economics and Business, 7(1), 269-278. https://doi. org/10.13106/jafeb.2020.vol7.no1.269

Vito, G. F., Higgins, G. E., \& Denney, A. S. (2014). Transactional and transformational leadership: An examination of the leadership challenge model. Policing: An International Journal of Police Strategies \& Management, 37(4), 809-822.

Wagner III, J., \& Hollenbeck, J. (2010). Organizational behavior. New York, NY: Routledge.

Walumbwa, F. O., Wu, C., \& Orwa, B. (2008). Contingent reward transactional leadership, work attitudes, and organizational citizenship behavior: The role of procedural justice climate perceptions and strength. The Leadership Quarterly, 19(3), 251-265.

Wangenheim, F., Evanschitzky, H., \& Wunderlich, M. (2007). Does the employee-customer satisfaction link hold for all employee groups? Journal of Business Research, 60(7), 690-697.

Yaghoubipoor, A., Tee, O. P., \& Ahmed, E. M. (2013). Impact of the relationship between transformational and traditional leadership styles on Iran's automobile industry job satisfaction. World Journal of Entrepreneurship, Management and Sustainable Development, 9(1), 14-27.

Yang, Z., \& Peterson, R. T. (2004). Customer perceived value, satisfaction, and loyalty: The role of switching costs. Psychology \& Marketing, 21(10), 799-822.

Yammarino, F. J., Spangler, W. D., \& Dubinsky, A. J. (1998). Transformational and contingent reward leadership: Individual, dyad, and group levels of analysis. Leadership Quarterly, 9(1), 27-54.

Yoon, Y. S., Lee, J. S., \& Lee, C. K. (2010). Measuring festival quality and value affecting visitors' satisfaction and loyalty using a structural approach. International Journal of Hospitality Management, 29(2), 335-342.

Zeithaml, V. A., Bitner, M. J., \& Gremler, D. D. (2006). Service marketing: integrating customer focus across the firm (4th ed.). New York, NY: McGraw-Hill/Irwin. 